\title{
Historians as Activists: History Writing in Times of War. The Case of Ukraine in 2014-2018
}

\author{
Yuliya Yurchuk* (1) \\ Department of History and Contemporary Studies, Södertörn University, Sweden \\ ${ }^{\star}$ Corresponding author. Email: yuliya.yurchuk@sh.se
}

\begin{abstract}
This article elucidates the role of historians in times of war and the peculiarities of popular history narratives written by historians who became activists. The article focuses on historians who call themselves "Likbez. Historical Front." This cohort gave rise to a new professional species-activist historians-who are different from so called memorians or propagandists, who work in service of authorities. Likbez historians tried to use their power to influence and promote their activist agenda not only in the realm of memory and history but also in reformation of state institutions. I argue that for Likbez historians, securitization of the past is the main strategy employed for producing historical knowledge. Historians' work is a part of postcolonizing process observed in Ukrainian society since the Maidan protests. As the analysis shows, popular history narratives written with an open activist agenda are a result of many compromises made by scholars in the intersection of several factors: professional ambitions, political and civic aims, social and political context, popular expectations, and market environment. In line with the increased attention to agency in memory studies, this article demonstrates that historians have a much more nuanced relation to power than straightforward opposition or co-option.
\end{abstract}

Keywords: Ukraine; history writing; memory; popular history; activism; securitization; postcolonizing process; empowerment

The terms often used to define the military conflict in eastern Ukraine ${ }^{1}$-information war, war of narratives, or hybrid war-underline the crucial role of information in the conflict (Khaldarova and Pantti 2016; Nygren and Hök 2016; Bolin, Jordan, and Stålberg 2016). One of the main topics used in this war of narratives is history. Indeed, history is used by Russian authorities to explain Russia's annexation of Crimea or Russia's right to "protect" Russians in Eastern Ukraine from the Kyivbased "fascists" (Gaufman 2017). Of course, it is not the first time that history has been politicized and misused for catalyzing conflicts, as demonstrated by the vast range of studies on memory wars in this part of the world (Burch and Smith 2007; Smith 2008; Mälksöö 2010). Still, the role of it in an ongoing military conflict, in which history is so intensely misused, is an understudied problem.

In the article, I approach a particular cohort of historians who organized the group "Likbez. Historical Front." From the very beginning of the Ukrainian-Russian conflict, these historians regarded their profession as a tool in warfare and positioned themselves as civic activists who strived to influence the situation. I scrutinize the role these historians played when the whole society underwent dramatic and turbulent transformations. What kind of popular history narratives were written by historians who saw themselves as actors in the military conflict? What type of relations were established between historians and the state authorities during war? How did historians position themselves in relation to the public when they became activists? These are crucial questions to ask about the role of historians during war.

\footnotetext{
(C) The Author(s), 2020. Published by Cambridge University Press on behalf of Association for the Study of Nationalities. This is an Open Access article, distributed under the terms of the Creative Commons Attribution licence (http://creativecommons.org/licenses/by/4.0/), which permits unrestricted re-use, distribution, and reproduction in any medium, provided the original work is properly cited.
} 


\section{Historians as Activists}

Historians hold a widespread view that there is an intense tension between the political authority that tries to direct the history-writing process and the professional historians who strive to avoid any political influence and stay loyal only to their vocation. Historians who actively engage in politics of history are often not regarded as true historians, even called memorians, who betray professional ideals in the service of politics (Ther 2006). While scholars in some disciplines encourage their students to be involved in societal life and even to become activists, historians rarely do so. On the contrary, history implicitly discourages professional activism as it arguably derails a scholar from ideals of objectivism. ${ }^{2}$ Despite the proclaimed ideals of neutrality and rejection of normativity, it is not seldom that historians become involved in the political and societal life of the country where they live or whose history they study. Historians influenced by historical culture not only reproduce the ideas ruling in the society (Lundell 2017; Rüssen 1994; Sindbaek 2012) but also have the potential to bring up changes to the society. Moreover, since the rise of the historical profession in the 18th century, historians have often played the role of public intellectuals who provided society with orientation in questions not only of the past but also of the present (Berger 2019).

Indeed, historians today play an important role in peace, justice, and reconciliation processes (Wittner 2007; Gregson 2009). Some groups of historians, such as the Subaltern Studies Group or British History Workshop, have explicit activist agendas aimed at giving voice to those who are not in the position to be seen and heard. Scholars who deal with postcolonial countries, or with countries where open discussion of the past is suppressed, often produce texts which can play crucial roles in political and social shifts. That is why it is not seldom that such texts are censored or even banned. For instance, Benedict Anderson's works on Indonesia were banned, and he was not allowed to enter the country for about 30 years. Yet, his works had an enormous impact on the selfimage of Indonesia after the toppling of Suharto's regime (Anderson 2016). In Poland, the books of Jan Gross' Neighbors and Fear triggered a heated discussion on Polish identity (Gross 2000; 2006; Törnquist-Plewa 2014; Zubrzycki 2017). ${ }^{3}$ In Ukraine, Robert Conquest's book on the famine in 1932-33 laid ground for one of the most meaningful themes of Ukrainian national memory, which became a part of identity politics when Ukraine became independent (Conquest 1986; Dietsch 2006; Kasianov 2010; Applebaum 2017). These examples demonstrate that it is indeed not seldom that historians play an important societal role, willingly or not. Most often, though, they play this role as individuals, not as a collective. What is special with the group of historians I study is the fact that they act as a group in the context of military conflict. These individuals purposefully united their professional skills and thinking minds for achieving common aims. The goals they had and the ways they wanted to achieve them are discussed in the sections below.

\section{Likbez. Historical Front: Becoming Activists}

The group Likbez. Historical Front (henceforward Likbez) was started in spring 2014 when the conflict in Eastern Ukraine began. Historians' mobilization went in line with the remarkable mobilization of civil society at that time (Ukraiins'kyi Forum Blahodiinykiv 2015). In this regard, Likbez was one of many civic initiatives organized by professionals with the aim to counteract the Russian information offensive. Around the same time, StopFake was organized by former graduates of Kyiv Mohyla School of Journalists, and Information Resistance was formed by former intelligence and military professionals to fight Russian propaganda. These civic organizations of professionals are a continuation of civic activities initiated at Euromaidan (November 2013-February 2014). During the first weeks of the protests, some IT workers formed Cyber Hundred, and some translators organized Voices of Ukraine, providing their professional services for Euromaidan purposes. Medical specialists also acted as an organized group of professionals, since the first victims were killed on Euromaidan in January 2013 (Stepurko et al. 2014).

Although the protests finished, civil societies formed by professionals continued to provide services to keep the state functioning. It was the most vulnerable moment for state institutions. 
Then, President Yanukovych fled the country, the Parliament was paralyzed, and the Russian Federation annexed Crimea and supported the armed groups in Eastern Ukraine. It is worth studying professionally driven activism where professional skills are the main resource and tool in activist agendas. As the question of journalists facing the challenges of professionalism and patriotism in Ukraine was already tackled (Gaufman 2015; Horbyk 2019; Voronova 2019), the question of historians facing the similar challenges remains mainly understudied. Iryna Vushko's article (2018) about Likbez concentrated mainly on the analysis of the content of their ten-volume, popular history project. In my study, I concentrate on the motivations, strategies, and results of historians' works. The broader focus on Likbez as a product of unique combination of time, place, and actors can also illuminate the particular context in which this project evolved from 2014 to 2018. The Likbez historians saw their role as activists through the possibilities given by their profession. They believed that by doing what they are trained to do-writing history-they could change the country and even contribute to its security.

I argue that since the beginning of the Russian-Ukrainian conflict in Eastern Ukraine, Likbez historians presented history as a matter of security. They explicitly wrote their historical texts in response to narratives disseminated by Russian media, and they saw themselves and their profession as weapons in the propaganda war. In this way, historical narratives were framed as issues of national security. In the beginning, securitization of history provided the main explanatory framework that was used to counteract Russian propaganda in short articles disseminated online. Later, securitization laid a theoretical and ideological basis for popular history writing disseminated through multiple volumes. In the course of their engagement as activists, the Likbez historians strengthened their own positions as scholars. Their new role as public intellectuals helped them to claim back the status of intelligentsia that had been in decline since the 1990s. In this way, historians built up a peculiar type of relationship to political power. As it will be shown, Likbez activities were acknowledged and symbolically rewarded by the state. Within four years, they published an enormous scope of literature, popularized their works by giving lectures throughout the country, and became regular guests on television shows. The case of Likbez also elucidates a more general situation in Ukraine after Euromaidan. The popularity of Likbez books and lectures indicates that a large part of Ukrainian society underwent a process of self-(re)articulation in which Likbez histories provided ad hoc narratives.

I start with the introduction of the theory, where I draw on the theory of securitization and argue that history was used as a matter of security by historians who saw themselves as active participants in the information war. I also use the concept of postcolonizing process to understand the context in which the historians' activities evolved from 2014 to 2018. I also present the background of intellectual life in post-1991 Ukraine, without which it is difficult to understand in what situation the scholars in Ukraine work. Then, based on interviews with Likbez historians and analysis of the books published within the project, I discuss strategies used when writing history and analyze the main features of the produced narratives. I finish the article by reflecting on the role of historians as activists during war.

\section{From Securitization to Postcolonizing Empowerment}

I draw on the theories of securitization as elaborated by the Copenhagen School of Security Studies. According to Buzan $(1998,21)$, securitization refers to the process of making a certain issue into a matter of security through a securitizing speech act. Framing history as a matter of security is not uncommon (Strukov and Apryshchenko 2018). Political scientist Maria Mälksöö (2010) effectively demonstrated how the securitization of the past took place in Estonia and Poland. There, the politics of memory were framed as a matter of security, calling for recognition of the right of these countries to tell their own story of the past differently from the Soviet and Russian versions. In her study on Russian use of the past regarding Ukrainian conflict, political scientist Elizaveta Gaufman (2015) showed how the past was used in a securitizing move by Russia, who attempted to depict the 
Ukrainian government and military as an existential threat through calling them fascists. By referring to the past threat, Russia enables "the legitimization of extraordinary measures ostensibly aimed at combatting this threat" in the present (Gaufman 2015, 143). Media scholar Jade McGlynn also demonstrated that by presenting the Great Patriotic War as a frame though which one should understand events in Ukraine in 2013 to 2014, the media and government in Russia guided domestic political perceptions of the Ukrainian crisis (2018).

In Ukraine too, the past was discussed in the context of ontological security since the 1990s, when a new national history of Ukraine was presented by national democratic parties as the main safeguard against the perceived imperial threats coming from Russia (Yurchuk 2017). Media scholar Mykola Makhortykh (2018) showed how memories of revolutions and wars were employed for the social construction of security issues during the Euromaidan and at the beginning of the military conflict. In spring 2014, when the fears and anxieties of losing independence and sovereignty proved real, when a part of the Ukrainian territory was annexed by Russia and the armed conflict began in Eastern Ukraine, the securitization of the past intensified. The package of the Laws on Decommunization ${ }^{4}$ that was adopted by the Parliament in April 2015 explicitly presented history as a matter of country's security (Törnquist-Plewa and Yurchuk 2019).

The case of Likbez shows how a securitization of the past is realized on the level of activities of professional historians. The securitizing approach is evident not only in the histories Likbez produces but also in the motivations of historians. As one of the Likbez activists commented, "Some of us went to front, some of us started Likbez" (Pavlov 2017). In this way, history was analogous with weapons and historians with soldiers. Moreover, only a particular kind of history acquires a weapon status. In words of Kyrylo Halushko, the leader of Likbez, this kind of history is truth: "The weapon of the contemporary Ukrainians [...] is the [...] truth and unstoppable search for truth" (2016f, 4). Moreover, true history must be free from censorship. Only this ensures the building of a free country: "We do not need censorship, we need a free country" (2016f, 4). How this particular popular history narratives are written is one of the main questions of this article.

To understand how the Likbez activities evolved from 2014-2018, as well as how they were received by the public, I use the concept of postcolonizing process as elaborated by historian John Cash. He writes that the internal postcolonizing process is the situation "in which many inequalities and perverse effects of the colonial past are slowly and unevenly being addressed and undone" (Cash 2017, 387). Cash considered the postcolonizing process as distancing from the friend-enemy ideology. He referred to the situation in Northern Ireland and argued that after the signing of the Belfast Good Friday agreement of 1998, Northern Ireland found itself in the counter-intuitive situation in which the shift away from the violence of the past increased ontological insecurity of the citizens (Cash 2017). A similar situation was seen in Ukraine and the Baltic states after 1991, when the ontological insecurity was high, although there were no grounded reasons for this. As result, the collective memory was often formed against the background of fears and anxieties that the countries' sovereignties were under threat (Mälksöö 2010; Yurchuk 2017). Paradoxically, when Ukrainian sovereignty was under threat in 2014 during the beginning of the war in Eastern Ukraine, the historians I analyze started to move from history writing influenced by fears to history writing influenced by hopes. As I argue below, in these popular history narratives new futures are imagined where the enemies of today can be partners of tomorrow.

Taking into consideration the popularity of the histories produced by Likbez, I assume that a part of Ukrainian society together with Likbez historians is undergoing the postcolonizing process in which it rearticulates itself vis-à-vis both its past colonial power-Russia-and the West. Historian Ilya Gerasimov described Euromaidan protests as "the last postcolonial Revolution" in which the former colonial subject was getting rid of residues left by former colonial powers (2015). Following that interpretation, I argue that Likbez historians try to write a popular history of Ukraine from the position of the country which is liberating itself from its colonial legacies. 


\section{The Institute of History as a Setting for the Historical Front}

To understand how Likbez historians work, I examine the broader context of professional scholarly work in Ukraine. Most historians of Likbez work at the Institute of History in the Ukrainian Academy of Sciences. Historians as well as other scholars in Ukraine found themselves in quite a deplorable situation after 1991, especially if one compares it with the status they had in the Soviet Union where historians were regarded highly in the hierarchy of scholars. History was treated as a part of state ideology purposed to supply evidence for the historical inevitability of the Soviet regime and the progressive character of its ideology (Sklokin 2014). The history department in its very essence has always been the universities' ideological leader (Masliichuk and Portnov 2012). In Soviet Ukraine, this meant severe censorship of writing on Ukrainian history (Portnov and Portnova 2017). After the collapse of the Soviet Union, a lack of funding and of understanding how science should function in market conditions resulted in a loss of high status of scholars. In new circumstances the society needed a new type of history. The books of diaspora historians were brought to Ukraine and used as the basis for new historical narratives.

As a result, the old Soviet historiographic model was substituted with a new national paradigm, in which a master narrative was focused on the Ukrainian nation's struggle for the state's independence, concentrating mainly on the ethnic concept of the nation (Yekelchyk 2011). Later, using Western critique to reveal failures of the national paradigm, the new national framework was criticized by younger historians who worked in a broader transnational paradigm (Kasianov 2009; Yakovenko 2009; Plokhy 2012). By the time that the new generation of historians-who later became organizers of the Likbez project-started their work in the Institute, the adherents of several distinctive approaches to history found their place under the roof of the Soviet-bred Institute of History. In Likbez historians' works, one can see the echo of the old institutional legacies: the belief that historians are responsible for part of state's ideological work. Yet, these legacies mutate as the historians try to propose ideational constructs in the state where ideological transcript is basically absent (in contrast to the Soviet times when the state had a strong ideological transcript and historians had to write themselves into this script). To a certain degree, by working on the Likbez project, a young generation of historians built up a new institution separate from the Academy of Sciences while continuing their official work in the academy and history department at different universities. This form of organization, which can be regarded as a network of professionals, is more fitted to the changing and dynamic times than the old-style academy. Likbez has a fluid and porous structure that easily absorbs new members who often have only a situational affiliation to Likbez with a purpose to work for some concrete task. Moreover, Likbez historians face challenges of market oriented publishing, collective writing, and work with media and mass public.

\section{Historians as Citizens: Maidan as a Point of Gathering}

Formally, Likbez started its activities as an organization by launching their website in September 2014. Informally, though, the group of historians that would form the core of Likbez met during the Euromaidan protests in December 2013. This group consisted of mainly the 1996 graduates of the History Faculty of Kyiv Shevchenko University. In 2013, most of them worked at the Institute of History or history departments in the capital's universities. They gathered on Maidan Nezalezhnosti (Independence Square) in Kyiv to join thousands of other protestors who demanded the resignation of the government.

The violent dispersal of students by the police that happened in the morning of November 30 , 2013, marked a point of no return not only to the average protestor but also to the historians in question. As one of the historians commented, they came to Maidan to protect their children, meaning their biological children and their students (Pavlov 2017). It became clear for this group that gathered "to protect their children" that it was up to them to bring the change to the society where politicians cannot bring this change. "No one but us" (Nihto krim nas) was the main motivation of these historians for staying on Maidan (Pavlov 2017). The memories of the students' 
protests, which took place in October 2-17, 1990, in Kyiv and are often referred to as Revolution on Granite, framed the historians' narratives when they were asked about their motivation for gathering. As commented by Pavlov who mentioned the Revolution on Granite, "We did not want to be like our parents who chose salaries and stability instead of reforms" (2017). Then, in December 2013, these historians felt that they became the subjects of history, and this sense empowered them to further actions.

On Maidan, these historians were asked by some of their students to deliver lectures at the Free University of Maidan (Vil'nyi Universytet Maidanu), which was spontaneously organized to entertain the protestors. The historians understood that history mattered not only for professional historians but also for people who wanted to know more about the past. More importantly, these historians realized how little they could propose in terms of published books accessible for a wider readership. Historians on Maidan saw themselves as citizens who came to the main square of the capital when their country was amid turmoil, and at the same time they saw themselves as professionals who could use their profession for civic purposes. Some historians combined their civil courage with professional enquiry when they were writing down their participant observation notes in the middle of the protests (Yurkova 2018). So, civic and professional roles merged: historians came to Maidan as citizens, but they did not leave their professional identities at home, instead they combined the roles.

In one of the Likbez books, Kyrylo Halushko, the leader of the group, explicitly describes the civic role of Likbez historians:

Historians are also citizens like all others. They live in the same country and in the same world; they worry about the same problems as their compatriots. But historians have access to information which is highly interesting and needed by a broader public. That is why we are eager to share this knowledge and help our community to stand up and carry on through these hardships. (2016d, 1-2)

In this way, by rhetorically putting himself in the ranges of their readers, Halushko presents historians both as citizens and as intellectual elites who possess knowledge that can be shared. The emphasis on the hard time that the readers and historians live through adds to better understanding of the importance of history for the present challenges. At the same time, underlining their professional role as bearers of much needed knowledge in turbulent times, the author places historians in the prestigious position of national educators that bring enlightenment to the masses.

\section{Beginning Official Activity: Website and Imagined Audiences}

Formally, Likbez started by launching its website in September $2014 .^{5}$ Central to the group was historian and sociologist Kyrylo Halushko. Previously, he was a driving force in a smaller publishing project popularizing Ukrainian history written in Russian. ${ }^{6}$ After Maidan, his ideas on popular history reactivated. More importantly, these ideas were now shared by other colleagues who were eager to do something in the spirit of Euromaidan after the protests ended.

Initially, the Likbez website was published in Russian. As explained by Likbez historians, at first the project was aimed at a Russian speaking audience influenced by Russian propaganda myths (Halushko 2017; Prymachenko 2017). The project was conceptualized as a tool for debunking these myths and changing the views on history that were perceived by Likbez as incorrect. As commented by Yana Prymachenko, a historian involved with the project from its start, "in the very beginning it was a Russian-language project targeting Russian and Russian-speaking audiences who did not understand what was true and what were lies in Russian media" (2017). Soon historians realized that it was "the pro-Ukrainian public who wanted to know more," who were most interested in the material on the Likbez website, and that this audience was ready to read in Ukrainian (Prymachenko 2017). In such a way, one can speak about a confirmation bias, as the information produced by Likbez was first and foremost welcomed by the audience that was ready to receive the narratives 
different from those inherited from the Soviet times that were also disseminated by Russian official discourse. Likbez historians provided narratives for those who were already looking for the narratives they wanted to hear, not necessarily for those that could change their minds. One can also speak about the language bias of the historians who associated language with inclination to believe in a certain ideology. In reality, the interest in material was dictated not so much by a language spoken but by the interest in a specific kind of narrative.

\section{Likbez Expanding Its Activities}

After a year of their activities, Likbez historians realized that the format of the website was not sufficient to cover public needs, and they decided to organize lectures and publish books. Since 2016 they have published ten volumes of History without Censorship and some other books, including History of Ukrainian Army, War and Myth: Unknown Second World War, and more. So many Likbez books published in such a short time is a truly unique case of the popular history project in Ukraine (Vushko 2018, 113). After reading the books produced by Likbez, I concluded that the main approach to history in writing these books is the demonstration of the fluidity of history and political processes that indicates that no country in the present (mainly Russia) can claim its exclusive right on certain territories. Coupled with the securitization strategy, such an approach simultaneously addresses the problem of the present conflict and develops a new way for professionals to write popular history narratives.

All Likbez books were published by Kharkiv based publisher Klub Simeinoho Dozvillia. Kyrylo Halushko, commenting on their collaboration with the publisher, underlined that Likbez became a commercially successful project; that is why the publisher was eager to publish more of their books (Halushko 2017). The publisher printed 8,000 to 21,000 copies for each volume of History without Censorship, a significant number for the Ukrainian publishing market. ${ }^{7}$ Some of the scholars published their own monographs or edited volumes under the umbrella of Likbez at the same publishing house (Buyskykh 2018; Kis 2017; Pinak and Khmyr 2017; Lobodaiev 2017). In doing so, by working on Likbez the scholars not only contributed to development of the project but also strengthened their status as intellectuals in the society. For instance, some of the Likbez historians took part in Declassified History (Rozsekrechena Istoriia), a talk show broadcasted on the television channel UA: Pershyi. In 2016, Likbez began work with Kyiv's Museum of History, where historians held weekly lectures. These lectures were well attended and free of charge (a visitor must only pay an entrance fee to the Museum, which is less than one Euro). Between 2015 and 2018, historians also gave lectures in other towns throughout Ukraine. Historians presented the main aim of their activities as the enlightenment of the people and dissemination of historical knowledge that was perceived to be important for winning the ongoing war. One of the Likbez historians summarized the project's mission in the following way:

We are trying to encourage rethinking of those ideas about the past which are based on imagination (vyhadkah) and myths; it means that we are rather drawing attention to the drawbacks of already present knowledge than forming the knowledge from scratch [...]. Our task is to overcome the historical illiteracy [...] so that there will be no people who are uneducated in history. (Yefimenko 2016; emphasis in the original)

Here the scholar explicitly refers to the Soviet newspeak "likbez"- the politics of liquidation of illiteracy launched in the 1920s-which gave the name to the project. The public is seen as bearers of incorrect history disseminated by the Soviet myths. This incorrect history needs correction in the eyes of Likbez historians. What is the correct history in their opinion, then?

\section{Histories Produced by Likbez: From Security to Liberation?}

What kind of history narratives are the historians of Likbez writing and popularizing? Prymachenko commented on the content of their work: "I see this as a decolonial project. We cannot write 
critical history before we create the narrative that later can become more complicated and subject to professional critique. We need this descriptive history first, and after this we will come to analytical and critical perspective" (2017).

Indeed, the Likbez histories, when read by professional historians, may seem simplified and lacking theoretical and conceptual discussion. It is obvious that aiming at the broad public, the authors try to find a balance between scholarly writing and mass readership. Oksana Yurkova (2018), the historian from the Institute of History of the Academy of Science who has worked for the project from the very beginning, reflected that all these books, although popular in form, are first of all scholarly works because they undergo a strict scholarly review process by professional colleagues. Moreover, the work on the project is seen as a pushing factor that stimulates the scholars to pose new questions and do more research (Yurkova 2018). However, Likbez books do not follow traditional academic standards as they are written for mass readership. Thus, traditional academic writing references are absent in the Likbez series, although most of the books provide a list of recommended literature.

Halushko romantically characterized the group as a "free association of free individuals" (2017). The themes which are tackled and the writing styles of the authors might differ in the same book. This approach is explained by Halushko: "Ukraine is a country in which historical discipline is rich, and here researchers have different views and evaluations which is the strength, not the weakness" (2016f, 34). Put another way, "Ideology of our project is revealed through the mere words 'without censorship' [...]. Something can be disliked in Ukraine, in Russia, or somewhere else. But we are scholars, loyal to our profession" (Halushko 2016e, 4; emphasis in the original). These claims show that historians explicitly present themselves as subjects who are independent vis-à-vis the views both from Russia and the West. Their profession becomes the empowering tool that allows them to take positions and act.

Main ideology which can be deciphered in all Likbez histories is the primacy of Ukrainian statehood and sovereignty. Historians think how the past can help protect sovereignty in the present. As commented by Vasyl' Pavlov, who is actively engaged in (re)writing military history of Ukraine and who closely worked with the Ministry of Defense of Ukraine, even military defeats of Ukrainian forces in the past have to be conceptualized in such a way that they can be used for the victories on the battlefields in the present (2017). In this way, historians turn to the view on history as magistra vitae, searching for the examples that could motivate and encourage present generations. In this regard, the needs of the present come before the analytical striving in writing activist popular history narratives, and the past is framed as a matter of security. Through securitization of the past, historians defend their narratives as something that can guarantee victory in the ongoing war.

Through a thorough reading of Likbez books, I distinguished five characteristic features that shape historical narratives of Likbez: (1) importance of the present moment and presentation of history as a result of the plethora of choices; (2) anti-Soviet rhetoric; (3) emphasis on the notion of civic instead of ethnic nation; (4) accessibility of writing; (5) and an entertaining form of writing realized through the myth-busting storytelling. Below I will discuss these features in more details and show how they work for the purposes of securitization and popularization of history as well as how they reflect the postcolonizing process.

\section{The Present Moment as the Main Vantage Point}

The founder of modern Ukrainian historiography, Mykhailo Hrushevskyi (1866-1934), published his history of Ukraine-Rus' in ten volumes. He regarded Ukraine as a nation that existed through centuries, whose history culminated during the First World War and after it (Plokhy 2005). Likbez published their series History without Censorship also in ten volumes. On the one hand, Likbez followed the tradition started by Hrushevsky to see the history of Ukraine as separate from other Eastern Europeans nations, mainly Russia (Vushko 2018, 114). On the other hand, Likbez 
historians work in the conditions of the 21st century, aware of all the turns in humanities and equipped with results of technological and scholarly progress.

The Likbez historians try to inscribe Ukrainian history into the larger European and world history. Their histories are shaped by the needs of present moment and should be read from the presentist perspective. In the introductions to almost all the volumes of History without Censorship, Halushko emphasizes the importance of the present moment when "many Ukrainians started to think again about the origins of their state and nation, relations with old neighbors" (2016e, 3). Moreover, Halushko adds that the difficult times of the present are decisive for the Ukrainian state and nation building because they show Ukrainians' readiness for new challenges:

We all realize the fact that history of Ukraine was created not in the past, but it happens in the present during extremely nervous and hard years of 2014-2015. As it happened, the independent state, which was created in 1991, has finished its period of "looking for its Self" and found itself facing the challenges that pose the question to its own vitality [...] We realized that we [Ukraine's citizens] are ready for these challenges. Because it was not yesterday that Ukraine had been born, its people have been living on these lands for thousands of years. They were changing their name and their state belonging, but they have not changed its essence and desire for independent life. (2016d, 3)

This emphasis bears a strong empowering momentum for the readers who identify themselves with the present moment because "the history is written now." This is exactly how historians write their popular history narratives as a part of what I call the postcolonizing process: presenting the country as shifting from a position as a former colonial subject toward its existence beyond the framework of anti-colonial relations. The Likbez historians do not provide the readers with explicit theoretical frames discussing postcolonial or anti-colonial perspectives, but my thorough reading of their books let me see their project as a realization of a postcolonial perspective. Whereas the main imperative of the anti-colonial perspective was to emphasize that Ukraine is a primordial nation (the perspective presented by Hrushevskyi), the main imperative in postcolonizing history writing is to emphasize that the Ukrainian nation is constantly changing. Securitization strategy is realized by emphasizing that the result of these changes-the present Ukrainian state-should be protected: "We show how Ukraine was 'making itself: [...] how it was becoming the state, the territory with its own borders which should be protected now with arms. These borders appeared not by accident and were often gained by paying a high price" (Halushko 2016c, 6).

In a similar way, when the imperial rule is discussed by Likbez authors, it is stressed that colonialism and imperialism are still the threats of today $(2016 \mathrm{~g}, 11)$. Yet, in contrast to the past conceptualization of these threats, Likbez historians try to convince their readers that dynamics and change are a driving force of history. Thus, no threat can last forever and enemies of today can be partners in the future. Representations of the Soviet past by Likbez historians demonstrate this approach most vividly.

\section{Sovietness as the Main Enemy}

Soviet past is presented as a threat to prosperous development of the country in the interviews with the historians, their texts on the website, and their books. Unsurprisingly, three volumes of History without Censorship are devoted exclusively to the Soviet period. Special attention is paid to the period of 1917-1921, which shows that historians look at this period as the crucial moment of history in which Ukraine had a chance either to take the Soviet path proposed by Bolsheviks or to build the independent nation. The main idea common to these books is that the Soviet past is gone and now Ukraine has a chance to get rid of the Soviet ghosts.

It is important to emphasize that the Soviet past is presented not as something alien to Ukrainian history. Ukraine during the years of Soviet rule is presented as an agent of its own fate. In contrast to anti-colonial histories that present Soviet rule as alien and brought from outside, Likbez historians 
emphasize that it is a mistake to think that "communism in Ukraine was exclusively of Russian origin," since it had Ukrainian roots as well (Yefimenko, Prymachenko, and Yurkova 2017, 4). In such a way, the responsibility of the establishment of Soviet rule in Ukraine is shared by both Ukrainians and Russian Bolsheviks even if the Soviet choice is presented as a huge failure: "The virus of communism, which grew from the widespread socialist ideas in the beginning of 20th century, happened to contaminate Ukrainian society as well [...]. To the end of 1920s Ukraine was indeed the subject of Bolshevik politics, one of the parties, even if unequal, in the relation to the communist center" (Yefimenko, Prymachenko, and Yurkova 2017, 4-5).

As it is made clear in the volume, Ukrainian communists believed in the ideas proposed by Marxism (Yefimenko, Prymachenko, and Yurkova 2017). Although the authors explicitly regret the fact that Ukraine failed to build its own state in the 1920s, they also underline that it was the Ukrainian Socialist republic, not some alien structure, that appeared: "The Ukrainian state was defeated then. And the lands of our nation were split again. But in the part of the territory of Ukrainian People's republic appeared a Ukrainian Socialist Republic. Not Little Russian. Not NovoRussian ... Ukrainian. It might have been just a toy for the leaders in the Kremlin, yet it remained Ukrainian" (Halushko 2016 b, 4; emphasis in the original).

Thus, we see a complex evaluation of the Soviet past where the subjectivity of Ukraine is emphasized. The main problem for Likbez historians is not, though, the past but the present. They regard the people who believe in the advantages of the Soviet regime as the main public to whom they address their history. As Pavlov stressed, "these people may support Ukrainian statehood, they are patriots, but they believe in Soviet myths. The purpose of Likbez is to change these beliefs" (2017). Hence, the main logics behind the volumes about the Soviet past are to show the disadvantages of the communist regime even if supported by many Ukrainians.

Noteworthy, Likbez historians did not speak a lot about such obvious threats as Russian military or the separatists backed by Russia. Instead, the threats were in people's minds: "Some of us went to the front, some are involved in charity work, and some are involved in reformatting the minds" (Pavlov 2017; emphasis mine). Likbez was organized to do the latter. There is no distinction between Ukrainian and Russian speakers in this regard. They are both seen as the bearers of Soviet mentality. This mental Sovietness is presented by historians as a part of postcolonial syndrome, with which Likbez historians explain "troubles with the present independent Ukraine" because they are "problems of transition from dependence to freedom" (Halushko 2016g, 11).

This argumentation about Soviet mentality resembles Mykola Riabchuk's (2000, 2003) works on Ukraine, where he sees the Ukrainian population as divided between the majority of creoles who internalized the colonial visions of themselves and a minority of indigenous population who are opposing the colonial rule. This approach was widely criticized by other scholars (Hrytsak 2002). Likbez popular history narratives can be seen as presenting a middle way: they discuss Soviet mentality, but they do not present it as something alien. Soviet past is approached as a construction block in a long history of state and nation building. This middle way can be seen as a step from anti-colonial history writing to the postcolonizing process, where Ukraine is presented as a subject owning its history, including history of the Ukrainian Soviet Socialist Republic.

\section{The Civic Nation and Its Friends, Neighbors, and Enemies}

Likbez historians try to present the history of Ukraine as the long formation process of civic nation, which resulted from interaction between different ethnic groups who lived on the territory that is now Ukraine (Vushko 2018, 119). As Halushko commented, Likbez aims "to tell people that there is nothing to be ashamed of if we admit that our nation is not old, that it is forming even now; this is not something special about Ukraine; many nations were late in forming their states" (2017). 
This is a clear move forward from primordial to a constructivist view on nation. It is worth mentioning which nations are presented most often in regard of cohabitation and interaction:

Modern scholars do not reject the role of any nation from our history [...]. Ukrainians, Crimean Tatars, Bulgarians and Hungarians, [...] Poles, and Russians-these people all form contemporary Ukraine. Each nation has contributed to our common heritage in a certain point of history [...]. This constitutes our unique historical experience [...]. We cannot ignore thousands of years of our history because this is our reliable basement as a nation of the 21st century for building our common home. (2016f, 3-4)

Nevertheless, in this multiethnic construct there are nations who draw more attention than others, namely, Crimean Tatars and Russians. Reading books, one can conclude that there is a certain (re)discovery of Crimean Tatars in Ukrainian history. This trend is not only characteristic of this concrete history project. In general, in Ukraine after the annexation of Crimea there is a vivid interest in underlining the strong bond between Ukrainians and Crimean Tatars (Charron 2019; Zubkovych 2019) that serves for securitization of Ukrainian national borders, which were violated by Russia's annexation of Crimea. The statehood of Crimean Tatars is recognized as the only legitimate statehood within the territory of Ukraine:

Crimean Tatars are the only aside of Ukrainians' people of the contemporary Ukraine which had their own state history here. It was Tatars' Crimea that activated and stimulated appearance of Ukrainian Cossackdom that started to create modern Ukraine [...]. Our relations were not to be cut [...]. Today their [Crimean Tatars'] ancestors in the Crimea which is annexed by Russia are simultaneously Tatar and Ukrainian. (Halushko 2016a, 4)

The security crisis of today defines the way the history of Crimean Tatars is presented by the historians. It should be mentioned, though, that the tradition of presenting Crimean Tatars as friendly neighbors who lived on the peninsula for hundreds of years takes its origin in much earlier historiography that stressed Ukraine's exclusive rights to Crimea (Plokhy 2008). In this regard, Likbez continues this tradition and strengthens it.

Regarding the presentation of Russians, Likbez historians try to find a new and nuanced approach. Thus, historians emphasize that history changes and vectors of Ukrainian development change as well. There is nothing predestined in history, including relations between nations. For instance, while discussing the disintegration of Kyivan Rus', they stress that it would be a failure to think that Kyiv was destroyed due to the animosity between ethnic groups; instead it should be understood as the consequences of Kyiv's weakening power (Halushko 2016c, 111). In the same vein, the authors do not present the current war with Russia as having resulted from the eternal animosity between Russians and Ukrainians. They rather stress that the present war is a phase in the development of an ever-changing history. Thus, the conflict is explained as a result of the politics of Putin's regime (Zinchenko 2016, 10).

Russia in the Likbez paradigm is presented as the continuation of the improper Sovietness. Ukraine, on the contrary, is presented as a country having a chance to get rid of the Soviet burden. Time and again we see how important the Soviet past is in the works of Likbez. This is essentially the main Other against which the popular history narrative is written. This is exactly the realm where the postcolonizing process takes place. Likbez historians position Ukraine in the continuum where it goes its own way, distinct from the one proposed by former colonial powers. In this construct, Russia is not presented as an eternal enemy but as the neighbor with whom Ukraine has conflictual relations now, but this situation can change provided the change of the political regime in Russia.

\section{Accessibility, Entertainment, and Challenges of the Market}

To make a popular product is one of main purposes for Likbez, as commercial success can guarantee the existence of this project. Therefore, Likbez books must be easy to understand, free from difficult 
terminology and complex concepts. At the same time, these books must be of high scholarly standard, written by professional historians, not amateurs.

The original idea of Likbez to debunk myths is reflected throughout the works of Likbez historians. This approach perfectly serves the entertaining purpose that in its turn helps make the project popular. In whole, as Likbez historian Oksana Yurkova estimated, for almost 3 years of Likbez activities more than 200 myths were debunked in the articles on their website (Yurkova 2016). Noteworthy, it is not only myths from the Soviet past or current day Russia that Likbez historians debunked; Ukrainian historical myths are debunked as well. As another scholar who collaborated with Likbez noted in her book, Likbez is writing against "unreflexive, uncritical, and superficial products which are presented to the readers in the package of 'Ukrainian national idea' " (Buyskykh 2018, 17). To these myths belong stories based on traditional primordial imagination, which became quite popular in the 1990s, that traced Ukrainian nationhood from prehistoric times. Kyrylo Halushko characterized this approach as follows:

At the beginning we tried to respond to many propagandistic anti-Ukrainian historical myths and did it quite successfully. Then we realized that some Ukrainian historical myths also are harmful, as they blur the line between reality and alluring fantasy. That is why we believe that information about Ukrainian past based on facts and not on fantasies or ideological premises will help contemporary Ukrainians better understand their own views on the past events and form their own standpoint about the past, present, and future. (Halushko 2016c, 6)

By debunking Soviet and Ukrainian primordial myths, Likbez historians try to formulate a more nuanced approach to history, and simultaneously their emphasis on myth busting serves an entertainment purpose; hence, it also serves popularizing purposes.

We should bear in mind that in striving to popularize history, Likbez historians faced an important challenge of the contemporary world-market. The fact that Likbez books are published by a commercial publisher, whose main aim is to gain profit, puts some pressures on historians that they are not used to. These pressures were realized through demands to use certain covers, simplify language, or include illustrations which the authors initially did not like. Scholars admitted that sometimes the final product was not quite the same as expected but also that they should listen to the publisher's suggestions as they know the market better. It should be added that Likbez books are not the only popular history books available in Ukraine, which is why they compete with other projects who have similar purposes and strategies. ${ }^{8}$ In the end, the published books come as result of negotiations and compromises made by historians who are not only citizens, historians, and activists but also players at the commercial book market. Writing their books in a collective can be also seen as a historians' response to market demands as well as their willingness to adhere to academic standards. Such a form of publication is quicker, and at the same time coauthors share collective responsibility for their texts. Sometimes they write a series of chapters together, and sometimes each author writes his or her chapter individually and serves as a peer-reviewer for colleagues' chapters. In this way, both academic standards and market requirements for fast publishing are met. The vast number of books published in a short period of time by the same cohort of authors and the high professional quality of these books proves the effectiveness of such a strategy.

Considering the popularity of Likbez books (120,000 copies were sold), one can assume that the popular history narratives presented in these books is the kind of history the public wants to read. The least popular among the readers is the volume about the Second World War. ${ }^{9}$ Remarkably, this is the volume that aims to debunk the most vital of the Soviet myths, and at the same time this is the volume that raises the most questions and critical remarks.

\section{The Second World War as a Bone of Contention}

The book on the Second World War, From Reichstag to Ivo Jima, finishes the History without Censorship series. I argue that history of the Second World War is the field where critical approach 
to history with acclaimed diversity of opinions in previous volumes loses its ground and gives way to strengthening the myths propagated by the UINP. This is, though, not surprising and has several explanations.

The Second World War is mostly used by Russian propaganda describing Ukrainians as fascists, junta, and banderovtsi (Bonch-Osmolovskaya 2015; Gaufman 2015; McGlynn 2018). The latter term refers to the Soviet depiction of Ukrainian nationalist groups who were fighting against Soviets during and after the war. In the Soviet Union, non-Russian nationalists who fought against Soviets were constructed as Nazi-collaborators. Until today this image is vividly and effectively used in discussions trying to denigrate the Baltics or Ukraine (Yurchuk and Umland 2018). The distorted picture of Ukraine in the years of the Second World War also arrested the popular imaginary abroad. As Hausmann and Penter (2014) argued, in the German public sphere Ukraine is often presented through the Russian propaganda view as a Nazi collaborator while the Ukrainian victims are largely ignored. The UINP and Likbez want to fight against these narratives produced by Russian propaganda, but they are doing it in a counterproductive way. By glorifying Ukrainian nationalists and silencing their wrongdoings during the Holocaust, the UINP and the historians who adhere to the Institute's ideological agenda strengthen the views disseminated by Russian propaganda.

The main problem of the approach to the Second World War by Likbez is threefold: (1) onesided representation of Ukrainian-Polish conflict in 1943-44; (2) glorification of the Organization of Ukrainian Nationalists (OUN); and (3) silencing the role of the local population in the Holocaust.

The Ukrainian-Polish massacre in 1943-44 is presented by Likbez in line with the conceptualization of Ukrainian historian Volodymyr Viatrovych $(2012,2016)$, who sees the conflict as a Polish-Ukrainian war in which Ukrainians are presented almost exclusively as supporters of the nationalist movement under Bandera's leadership. Viatrovych can be called the most politically engaged memorian as he held the position of the director of the UINP from 2014 to 2019. He authored some of the chapters in the Likbez volume on the Second World War, where the OUN members are presented exclusively as fighters for Ukrainian independence. The collaboration with Nazis and participation in Holocaust are ascribed only to the Melnykites faction of the OUN while the Bandera faction is presented as the heroic anti-Bolshevik movement for liberation.

In the volumes on the Second World War, Ukraine is presented exclusively as a victim; the evaluation of history is made mainly from the vantage point of Western Ukraine while highlighting the anti-Soviet moods of the public. Moreover, the Allies are presented as traitors who betrayed Ukraine: "Instead of declaring the war against the USSR for Ukraine, the French and British made a proposition to the Kremlin to start negotiations about the possible agreement about mutual help" (Patryliak 2016, 8). The volume on history of the Second World War is written not from the point of the subject undergoing the postcolonizing process but from the point of the subject that is tormented by anticolonial resentments. Perhaps admitting to the cul-de-sac they reached by this volume, Likbez historians did not develop this topic further in their volumes, giving it to the elaboration of the UINP for whom it continued to be the most fruitful turf for producing memory politics. The unpopularity of this volume among the readers might gesture to the public fatigue with the topic of war, as the war is not something which takes place only on the pages of history books. The war became reality that directly touches the lives of many in Ukraine today.

\section{Concluding Remarks}

This article aimed to analyze what happens to history writing when it is written by activist historians in the context of an ongoing military conflict. In line with the increased attention to agency in memory studies, this article demonstrates that historians have much more nuanced relation to power than opposition or co-option. The case with Likbez shows that historians in times of troubles made history into a matter of national security and presented themselves as actors of the ongoing war. If we understand nationalism in terms of nation building, Likbez is definitely a nationalist 
project that is purposed not only at nation building but also state building; whereas the nation is presented in civic terms statehood is of prime value as its very existence is under attack.

In turbulent times, historians started looking for new theoretical frames and ways of popularizing historical knowledge. Instead of continuing an anti-colonial trend of history writing and blaming the former imperial powers for all Ukrainian problems, the Likbez historians implemented a postcolonial approach and tried to represent Ukraine as an independent actor in an ever-changing flow of history, in which the enemies of today could become partners in the future. This turn can be compared to the approaches in history writing applied by the Baltic States. While in the Baltic case EU membership gave a feeling of safety, in which no return to the sphere of influence of a former imperial power was fathomable (Mälksöö 2010), in the Ukrainian case the war in the east of the country was seen by historians as a point of no return into the sphere of Russia's influence. Paradoxically, the country's vulnerable position during turbulent times gave hope for Ukraine's subjectivity, at least on the part of Likbez historians.

Throughout the article, I argued that securitization became the main strategy employed in popular history writing by Likbez historians. In their works they present historical knowledge as an element of national security. This history narrative has a strong empowering potential for a society that looks for meaning in a suddenly shattered world. Activist historians provide narratives that fill in cracks opened by this shattering. Their histories rearticulate the past violence and injustices in a new way that emphasizes change and fluctuation. As a result, history writing becomes an element of the postcolonizing process, in which the past is unveiled without fears, resentments, or anxieties about reactions from outside (Russia and the West). This is reflected in a shift from brother-brother ideology to neighbor-neighbor ideology, even if these neighbors are currently at war. This shift is reflected not only in history writing but also in popular culture and can be symbolically marked by the poem of Anastasia Dmytruk, "We Will Never Be Brothers" (2014), which became viral on social media in early spring 2014 when Crimea was annexed by Russia. The popularity of this poem demonstrated the disillusionment felt by many people vis-à-vis Russia who also shared the brotherbrother ideology. These are the moods that Likbez project meets when popularizing new historical narratives.

From the very beginning of its existence, the work of Likbez historians was directed not only to reforming, rewriting, or reevaluating the history but also to bringing tangible change to the society. Some of Likbez historians even succeeded in working on reformation of state institutions, including the Armed Forces of Ukraine. For instance, Kyrylo Halushko has worked with the Public Council on National Unity at the presidential office since 2015, where he was consulting on questions related to history and history education. In 2018, Vasyl Pavlov, was officially employed as a leading expert in questions of patriotic education by the General Staff of the Armed Forces of Ukraine. It should be stressed that it was first in the realm of history writing, which began as one of the Likbez initiatives, that the historian together with his colleagues developed strategies for reformation of military education, which later were implemented by the Ukrainian Army. There was not direct demand from the side of the state, and historians had to work hard to be heard by state officials. As result, securitization of history transcended discursive practices and penetrated the field of politics. Likbez scholars underlined that their books are popular among soldiers. Soldiers and teachers at military universities are among the main consumers of Likbez histories. In 2017, the civil organization Informational Resistance organized a special initiative, Book Invasion (Knyzhkova navala), for popularizing the History Without Censorship series. They bought 500 books and distributed them among the people living in the prefront territories (Derzhavna Prykordonna Sluzhba 2018). Such merging of civil actions, political interest, and historians' initiatives demonstrate that historians and society put high stakes on history in the present. Moreover, the past is presented as a crucial element for building the future. The analysis of Likbez histories and activities demonstrates that these activist-historians differ from both memorians (Ther 2006) and propagandists, who act in service of authorities and frequently try to influence and discipline the power according to their civic and professional agendas. Close cooperation with the Institute of National Remembrance, which 
resulted in the publishing of the book that became the least popular among readers, shows that cooption with state institutions may be in fact counterproductive and play against civic initiatives.

The article discussed the books and the historians' activities between 2014 and 2018. This time frame is a distinctive period in the development of the Likbez project. In spring 2019, Ukrainian people voted for the new president, Volodymyr Zelenskyi. It is too early at the time of writing this article to draw any conclusions in respect of new trends in the politics of history, but one can see some contours of these changes. Volodymyr Zelenskyi's New Year's Eve's speech, in which he declared that it was not important what name the streets bear if they are illuminated, vividly demonstrates that he distances from the heroic memory politics established by the previous government (Televisiina Sluzhba Novyn 2019). In light of more tangible changes in respect to the volunteer movement on the part of new government, Halushko, the leader of Likbez, declared that he was leaving the Public Council on National Unity at the presidential office (Halushko 2019). ${ }^{10}$ In this regard, the future will show how historical activism will transform in Ukraine under the changed circumstances.

Disclosure. Author has nothing to disclose.

Financial Support. This research was made in the framework of the project "Propaganda and management of information in the Ukraine-Russia conflict: From nation branding to information war," financed by the Foundation for Baltic and East European Studies. The author is grateful for the Prisma Ukraïna three-month research fellowship at the Forum for Transregional Studies in Berlin that made it possible to finalise this article.

\section{Notes}

1 The military conflict in Ukraine-which is also defined in academic writings by the euphemism "Ukrainian crisis"-started in eastern Ukraine in summer 2014 following the Russian annexation of Crimea in spring of the same year. The conflict involves Ukrainian government forces, on the one hand, and local separatist groups and Russian military, on the other. See, for example, Wilson (2014) and Yekelchyk (2015).

2 It is more common to speak about a public sociologist than about a public historian in terms of active engagement with the public outside academia. When we speak about a public historian, we speak rather about professionals engaged in heritage, preservation, and oral history, less about history writing that pursues the aim to change the political and societal order.

3 The book of Jan Gross on the small Polish town of Jedwabne where the local residents killed almost all of their Jewish neighbors was first published in Polish (2000) and then in English (2001). In 2006, he published Fear: Anti-Semitism in Poland after Auschwitz, first in English and then in Polish (2008), which also raised a wave of criticism and discussion in Poland.

4 The Laws on Decommunization were adopted by Ukrainian Parliament in April 2014 and include four separate laws that are quite different in the historic themes, motivations, and subjects they address. However, in Parliament they were presented in one package, which made the discussion of their relevance very complicated. The laws include the following: The Law on the Commemoration of the Victory over Nazism in the Second World War 1939-1945; The Law on Condemnation of the Communist and National-Socialist (Nazi) Totalitarian Regimes in Ukraine and Ban on Propaganda of their Symbols; The Law on the Status and Commemoration of the Memory of the Fighters for the Independence of Ukraine in the 20th century; and the Law on Granting Access to the Archive of the Repressive Institutions of the Communist Totalitarian Regime 1918-1991.

5 The project remains accessible online: http://likbez.org.ua/en/.

6 From 2006 to 2008, Kyrylo Halushko organized the Lypynsky's Center (Viacheslav Lypynsky was a theoretician of Ukrainian conservatism, 1882-1931). His main aim was to draw experts of the topics of history and consult Tempora Publishing House on history books worth translating and publishing in Ukraine. In 2010, this publishing house published Haluskho's book Ukrainskii Nationalism: Likbez dlia Russkikh (2010). It was a history of Ukrainian nation building, 
accessible and easy to read. From 2008 to 2010, the same publishing house published four books of history titled Likbez-ABC. It was this name that was reactivated again in 2014.

7 To compare, 20,000 copies were printed for the latest novel by well-known writer Serhiy Zhadan, Internat [Boarding School] (2017).

8 Some media outlets have their own popular history products (like books published by the authors from Istorychna Pravda website, newspaper Den', or Tyzhden' magazine, etc.). Although it was not the aim of this article to compare these projects, it is worth mentioning that Likbez books are closest to the academic standards.

9 Yana Prymachenko (workshop presentation at "Constructing Ukrainian Narratives in Turbulent Times," Södertörn University, September 20, 2018).

10 In December 2019, the police arrested five volunteers who were suspected of murdering journalist Pavlo Sheremeta in 2016 (Hubar 2019).

\section{References}

Anderson, Benedict. 2016. A Life Beyond Boundaries. New York: Verso.

Applebaum, Anne. 2017. Red Famine: Stalin's War on Ukraine. New York: Doubleday.

Berger, Stefan. 2019. "Historical Writing and Civic Engagement: A Symbiotic Relation.” In The Engaged Historian: Perspectives on the Intersections of Politics, Activism and the Historical Profession, edited by Stefan Berger, 1-31. New York: Berghahn.

Bolin, Göran, Paul Jordan, and Pre Ståhlberg. 2016. "From Nation Branding to Information Warfare: The Management of Information in the Ukraine-Russia Conflict." In Media and the Ukraine Crisis: Hybrid Media Practices and Narratives of Conflict, edited by Mervi Pantti, 3-18. New York: Peter Lang.

Bonch-Osmolovskaya, Tatiana. 2015. "Combating the Russian State Propaganda Machine: Strategies of Information Resistance.” Journal of Soviet and Post-Soviet Politics and Society 1 (1): 175-217.

Budivska, Halyna, and Daria Orlova. 2017. "Between Professionalism and Activism: Ukrainian Journalism after the Euromaidan." Kyiv-Mohyla Law and Politics Journal, 3: 137-156.

Burch, Stuart, and David Smith. 2007. "Empty Spaces and the Value of Symbols: Estonia's 'War of Monuments' from Another Angle." Europe-Asia Studies 59 (6): 913-936.

Buyskykh, Yuliya. 2018. Kolys' rusalky po zemli khodyly. Zhinochi obrazy v ukraiins'kii mifolohii. Kharkiv: Klub Semiinoho Dozvillia.

Buzan, Barry, Ole Wæver, Jaap de Wilde 1998. Security: A New Framework for Analysis. London: Lynne Rienner Publishers.

Cash, John. 2017. “The Dilemmas of Ontological Insecurity in a Postcolonising Northern Ireland.” Postcolonial Studies: Postcolonial Bordering and Ontological Insecurities 20 (3): 387-410.

Charron, Austin. 2019. "Crimean Tatars' Postcolonial Condition and Strategies of Cultural Decolonization in Mainland Ukraine." In "Ukrainian - Crimean-Tatar Socio-Cultural Encounters," edited by Kratochvil Alexander. Special issue, Euxeinos: Culture and Governance in the Black Sea Region 9 (28): 26-46.

Conquest, Robert. 1986. The Harvest of Sorrow: Soviet Collectivization and the Terror-Famine. Oxford: Oxford University Press.

Derzhavna Prykordonna Sluzhba Ukraiiny. 2018. "Narodnyi deputat Ukraiiny peredav prykordonnym pidrozdilam zbirky patriotychnoii literatury.” March 22, 2018. https://dpsu.gov.ua/ua/news/Narodniy-deputat-Ukraini-Dmitro-Timchuk-per edav-prikordonnim-pidrozdilam-zbirki-patriotichnoi-literaturi/. (Accessed October 10,2019.)

Dietsch, Johan. 2006. Making Sense of Suffering: Holocaust and Holodomor in Ukrainian Historical Culture. Lund: Media Tryck.

Dmytruk, Anastasia. 2014. "Nikogda my ne budem bratiami" [We Will Never Be Brothers]. YouTube, March 19, 2014. https:// www.youtube.com/watch?v=Qv97YeC563Y (Accessed May 26,2020.)

Gaufman, Elizaveta. 2015. "Memory, Media, and Securitization: Russian Media Framing of the Ukrainian Crisis." Journal of Soviet and Post-Soviet Politics and Society 1 (1): 141-173.

Gaufman, Elizaveta. 2017. Security, Threats and Public Perception: Digital Russia and the Ukraine Crisis. New York: Palgrave Macmillan.

Gerasimov, Ilya. 2015. "Ukraine 2014: The Postcolonial Revolution.” Ab Imperio 32: 22-44.

Gregson, Sarah. 2009. “Oral Historian and Activist: 'Studs' Terkel (1912-2008).” Labour History 96: 233-234.

Gross, Jan. 2000. Sasiedzi: Historia zagłady żydowskiego miasteczka. Sejny: Fundacja Pogranicze.

Gross, Jan. 2001. Neighbors: The Destruction of the Jewish Community in Jedwabne, Poland. Princeton: Princeton University Press.

Gross, Jan. 2006. Fear: Anti-Semitism in Poland after Auschwitz; An Essay in Historical Interpretation. Princeton: Princeton University Press.

Halushko, Kirill. 2010. Ukrainskii nationalizm dla russkih. Kyiv: Tempora. 
Halushko, Kyrylo. 2016a. "Vstup." Lytsari dykoho polia. Pluhom i mushketom. Ukraiins'kyi shliahh do Chornoho moria, edited by Kyrylo Halushko. Kharkiv: Klub Simeinoho Dozvillia.

Halushko, Kyrylo. 2016b. "Vstup." Na bii za voliu. Peremoha cherez porazky. Ukraiina u viinah i revolutsiiah 1914-1921 rokiv, 3-5. Kharkiv: Klub Simeinoho Dozvillia.

Halushko, Kyrylo. 2016c. "Vstup." Narodzhennia kraiiny. Vid kraiu do derzhavy. Nazva, symvolika i kordony Ukraiiny, edited by Kyrylo Halushko, 5-7. Kharkiv: Klub Simeinoho Dozvillia.

Halushko, Kyrylo. 2016d. "Vstup." Pole Bytvy Ukraiina. Vid "volodariv stepu" do "kiborhiv". Voienna istoria Ukraiiny vid davnyny do siohodennia, edited by Kyrylo Halushko, 3-4. Kharkiv: Klub Simeinoho Dozvillia.

Halushko, Kyrylo. 2016e. "Vstup." Rus' “pislia Rusi”. Mizh koronoiu i bulavoiu. Ukraiinski zemli vid korolivstva Rusi do viis'ka, 3-5. Kharkiv: Klub Simeinoho Dozvillia.

Halushko, Kyrylo. 2016f. "Vstup." Tini zhadanyh predkiv. Vid sklavyniv do rusyniv. Pradavnia Ukraiina, Rus' i pohodzhennia ukraiinysiv, edited by Kyrylo Halushko, 3-4. Kharkiv: Klub Simeinoho Dozvillia.

Halushko, Kyrylo. 2016g. "Vstup." U kihtiah dvohlavyh orliv. Tvorennia modernoii natsii. Ukraiina pid skipetramy Romanovyh i Habsburhiv, 3-11. Kharkiv: Klub Simeinoho Dozvillia.

Halushko, Kyrylo. 2019. “Ofitsiino vyhodzhu zi skladu hromads'koii rady.” Istorychna Pravda, December 18, 2019. https:// www.istpravda.com.ua/columns/2019/12/18/156745/. (Accessed May 2, 2020.)

Hausmann, Guido, and Tanja Penter. 2014. “Der Gebrauch der Geschichte. Ukraine 2014: Ideologie vs. Historiographie.”In Gefährliche Unschärfe: Russland, die Ukraine und der Krieg in Donbas, edited by Manfred Sapper and Volker Weichsel. Special issue, Osteuropa 9/10: 35-50.

Horbyk, Roman. 2019. “In Pursuit of Kairos: Ukrainian Journalists Between Agency and Structure During Euromaidan.” Baltic Worlds 1 (12): 4-19.

Hoskins, Andrew, and Ben O'Loughlin. 2010. War and Media: The Emergence of Diffused War. Cambridge, UK: Polity Press.

Hrytsak, Yaroslav. 2002. "Dvadtsiat' dvi Ukraiiny.” Krytyka, April 2002. https://krytyka.com/ua/articles/dvadtsyat-dviukrayiny. (Accessed October 3, 2018.)

Hubar, Olena. 2019. "Natspoliciia zatrymala pidozrivanyh u vbyvstvi Pavla Sheremeta - Avakov.” Deutsche Welle, December 12, 2019. https://p.dw.com/p/3UhFP. (Accessed March 2, 2020.)

Jörn, Rüse. 2019. “Engagement: Metahistorical Considerations on a Disputed Attitude in Historical Studies.” In The Engaged Historian: Perspectives on the Intersections of Politics, Activism and the Historical Profession, edited by Stefan Berger, 32-50. New York: Berghahn.

Kasianov, Georgiy. 2009. “'Nationalized' History: Past Continuous, Present Perfect, Future...” In A Laboratory of Transnational History: Ukraine and Recent Ukrainian Historiography, edited by Georgiy Kasianov and Philipp Ther, 7-24. Budapest: Central European University Press.

Kasianov, Georgiy. 2010. Danse macabre: Holod 1932-1933 rokiv u politytci, masoviisvidomosti ta istoriografii (1980-pochatok 2000). Kyiv: Nash Chas.

Khaldarova, Irina, and Merve Pantti. 2016. “Fake News: The Narrative Battle over the Ukrainian Conflict.” Journalism Practice 10 (7): 891-901.

Kis, Oksana, ed. 2017. Ukraiinski zhinky v hornyli modernizatsii. Kharkiv: Klub Simeinoho Dozvilla.

Kohut, Zenon E. 2003. "The Question of Russo-Ukrainian Unity and Ukrainian Distinctiveness in Early Modern Ukrainian Thought and Culture." In Culture, Nation and Identity: The Ukrainian-Russian Encounter, 1600-1945, edited by Andreas Kappeler, Zenon E. Kohut, Frank E. Sysyn, and Mark von Hagen, 57-86. Toronto: CIUS Press.

Kohut, Zenon E. 2011. Making Ukraine: Studies on Political Culture, Historical Narrative, and Identity. Toronto: CIUS Press.

Lundell, Valter. 2017. Det omsrtidda arvet: Den kommunistiska erfarenheten i dansk och svensk historiekultur. Lund: Media Tryck.

Lobodaiev, Volodymyr, ed. 2017. Viina z derzhavoiiu chy za derzhavu? Selinas'kyi povstans'kyi rukh v Ukraiini 1917-1921 rokiv. Kharkiv: Klub Simeinoho Dozvillia.

Makhortykh, Mykola. 2018. “\#NoKievNazi: Social Media, Historical Memory and Securitization in Ukraine Crisis.” In Memory and Securitization in Contemporary Europe, edited by Vlad Strukov and Victor Apryshchenko, 219-247. New York: Palgrave Macmillan.

Mälksöö, Maria. 2010. The Politics of Becoming European: A Study of Polish and Baltic Post-Cold War Security Imaginaries. London: Routledge.

Masliichuk, Vladimir, and Andrei Portnov. 2012. “Sovetizatsiia istoricheskoi nauki po-ukrainski." Neprikosnovennyi zapas 2 (83). http://magazines.russ.ru/nz/2012/3/m20.html. (Accessed October 3, 2018.)

McGlynn, Jade. 2018. "Historical Framing of the Ukraine Crisis through the Great Patriotic War: Performativity, Cultural Consciousness and Shared Remembering." Memory Studies. Published online ahead of print September 27, 2018. doi: $10.1177 / 1750698018800740$

Nygren, Gunnar, and Jöran Hök, eds. 2016. Ukraina och informationskriget - journalistik mellan ideal och självcensur. Stockholm: Myndigheten för samhällsskydd och beredskap MSB.

Pantti, Mervi, ed. 2016. Media and the Ukraine Crisis: Hybrid Media Practices and Narratives of Conflict. New York: Peter Lang. 
Patryliak, Ivan. 2016. “Ukraiins'ke pytannia v mizhnarodnyh vidnosynah naprykintsi 1930-h rr. Pakt Molotova - Ribbentropa." In Vid Reihstahu do Ivodzimy. U polumii viiny. Ukraiina ta ukraiintsi u Druhii svitovii viini, edited by Yana Prymachenko, 512. Kharkiv: Klub Simeinoho dozvillia.

Pinak, Yevhen, and Mykola Chmyr, eds. 2017. Viis'ko Ukraiins'koii Revolucii 1917-1921. Kharkiv: Klub Simeinoho Dozvillia. Plokhy, Serhii. 2005. Unmaking Imperial Russia: Mykhailo Hrushevsky and the Writing of Ukrainian History. Toronto: University of Toronto Press.

Plokhy, Serhii. 2008. Ukraine and Russia: Representations of the Past. Toronto: University of Toronto Press.

Plokhy, Serhii. 2012. "Vyzvolena Klio: Teksty I konteksty Natali Yakovenko.” Krytyka, December 2012. https://krytyka.com/ua/ articles/vyzvolena-klio-teksty-i-konteksty-natali-yakovenko. (Accessed October 3, 2018.)

Portnov, Andrii, and Tetiana Portnova. 2017. "Soviet Ukrainian Historiography in Brezhnev's Closed City: Mykola/Nikolai Kovalsky and His 'School' at the Dnipropetrovsk University.” Ab Imperio 4: 265-291.

Riabchuk, Mykola. 2000. Dylemy ukrains'koho Fausta: gromadians'ke suspil’stvo i rozbudova derzhavy. Kyiv: Krytyka.

Riabchuk, Mykola. 2000. Vid Malorosii do Ukrainy: paradoksy zapizniloho nacietvorennia. Kyiv: Krytyka.

Riabchuk, Mykola. 2003. Dvi Ukraiiny: realni mezhi, virtualni igry. Kyiv: Krytyka.

Rüsen, Jörn. 1994. "Was ist Geschichtskultur? Überlegungen zu einer neuen Art, über Geschichte nachzudenken.” In Historische Faszination: Geschichtskultur heute, edited by Jörn Rüsen, Theo Grütter, and Klaus Füßmann, 3-26. Köln: Böhlau.

Sindbaek, Tea. 2012. Usable History? Representations of Yugoslavia's Difficult past from 1945-2002. Aarhus: Aarhus University Press.

Sklokin, Volodymyr. 2014. "Staiiuchy publichnymy: istoryky iak publichni intelektualy u postradians'kii Ukraiini." Krytyka 5 (6): 199-200.

Smith, David. 2008. "Woe from Stones: Commemoration, Identity Politics and Estonia's War of Monuments." Journal of Baltic Studies 39 (4): 419-430.

Stepurko, Tetiana, Vitalina Vitiuk, Anna Kvit, and Pavlo Kovtonyuk. 2014. "Medical Care on the Euromaidan: Who Have Saved the Lives of the Protesters?" Social, Health, and Communication Studies Journal 1 (1): 80-104.

Strukov, Vlad, and Victor Apryshchenko, eds. 2018. Memory and Securitization in Contemporary Europe. New York: Palgrave Macmillan.

Televisiina Sluzhba Novyn. 2019. “Hlava derzhavy zaproponuvav national'nu ideiu.” December 2019. https://tsn.ua/politika/ davayte-kozhen-chesno-vidpovist-na-vazhlive-pitannya-hto-ya-novorichne-privitannya-prezidenta-zelenskogo-1468050. html. (Accessed January 8, 2020.)

Ther, Philipp. 2006. "The Burden of History and the Trap of Memory.” Transit: Europäische Revue 30: 1-13.

Törnquist-Plewa, Barbara, and Yuliya Yurchuk. 2019. "Memory Politics in Contemporary Ukraine: Reflections from the PostColonial Perspective.” Memory Studies 12 (6):699-720.

Törnquist-Plewa, Barbara. 2014. "Rhetoric and the Cultural Trauma: An Analysis of Jan T Gross' Book Fear: Anti-Semitism in Poland after Auschwitz." Memory Studies 7 (2): 161-175.

Ukraiinskyi Forum Blahodiinykiv. 2015. “Postmaidanna blagodiinist' i volonterstvo - 2015.” December 9, 2015. https:// www.ufb.org.ua/postmajdanna-blagodijnist-i-volonterstvo-2015/. (Accessed October 3, 2018.)

Viatrovych, Volodymyr. 2012. Druha pols'ko-ukrains'ka viina, 1942-1947. Kyiv: Vydavnychyi dim Kyievo-Mohylians'ka Akademiia.

Viatrovych, Volodymyr. 2016. Za lashtunkamy "Volyni-43": Nevidoma pols'ko-ukrains'ka viina. Kharkiv: Klub Simeinoho Dozvillia.

Viis'kovo-Mors'ki Syly. 2018. “Istoriia ukraiins'koho viis'ka: Vasyl Pavlov proviv lektsii dlia viiskovyh moriakiv.” April $20,2018$. https://navy.mil.gov.ua/istoriya-ukrayinskogo-vijska-vasyl-pavlov-proviv-lektsiyi-dlya-vijskovyh-moryakiv/. (Accessed October 10,2019.)

Voronova, Liudmila. 2019. “Conflict as a Point of No Return: Immigrant and Internally Displaced Journalists in Ukraine.” European Journal of Cultural Studies. Published online ahead of print September 9, 2019. doi: 10.1177/1367549419869351.

Vushko, Iryna. 2018. "Historians at War: History, Politics and Memory in Ukraine." Contemporary European History 27 (1): 112-124.

Wilson, Andrew. 2014. Ukraine Crisis: What it Means for the West. New Haven: Yale University Press.

Wittner, Lawrence. 2007. “Combining Work as an Historian and Activist: A Personal Account." Peace and Change 32 (2): 128133.

Yakovenko, Natalia. 2009. Narys istorii Ukraiiny z naidavnishyh chasiv do kintsia 18 stolittia. Kyiv: Krytyka.

Yakubova, Larysa, and Yana Prymachenko, eds. 2016. V obiimakh strakhu i smerti. Bil'shovyts'kyi terror v Ukraiini, Kharkiv: Klub Simeinoho Dozvillia.

Yefimenko, Hennadii, Yana Prymachenko, Oksana Yurkova, eds. 2017. Na bii za voliu: Peremoha cherez porazky; Ukraiina u viinah i revolutsiiah 1914-1921 rokiv. Kharkiv: Klub Simeinoho Dozvillia.

Yefimenko, Hennadii. 2016. “Chomu ukraiins'koiiu nash proekt nazyvaiet'sia likbez a ne liknep?” October 23, 2016. http:// likbez.org.ua/ua/ukrayinska-chomu-ukrayinskoyu-nash-proekt-nazivayetsya-likbez-a-ne-liknep.html. (Accessed October 3,2018.) 
Yekelchyk, Serhy. 2011. "Bridging the Past and the Future: Ukrainian History Writing Since Independence." Canadian Slavonic Papers 53 (2/4): 559-573.

Yekelchyk, Serhy. 2015. The Conflict in Ukraine: What Everyone Needs to Know. Oxford: Oxford University Press.

Yurchuk, Yuliya, and Andreas Umland. 2018. "Introduction: Essays in the Historical Interpretation of the Organization of Ukrainian Nationalists." Journal of Soviet and Post-Soviet Politics and Society 4 (2): 29-34.

Yurchuk, Yuliya. 2017. "Reclaiming the Past, Confronting the Past: OUN-UPA Memory Politics and Nation-Building in Ukraine (1991-2016).” In War and Memory in Russia, Ukraine, and Belarus, edited by Julie Fedor, Markku Kangaspuro, Jussi Lassila, and Tatiana Zhurzhenko, 107-137. New York: Palgrave Macmillan.

Yurkova, Oksana. 2016. “Ubyvtsi mifiv: Likbezv programi'Rozsekrechena istoriia.' ” December 3, 2016. http://likbez.org.ua/ua/ ubijtsy-mifov-likbez-v-efire-programmy-rassekrechennaya-istoriya.html. (Accessed October 3, 2018.)

Zhadan, Serhii. 2017. Internat [Boarding School]. Chernivtsi: Meridian Czernovitz.

Zinchenko, Oleksandr. 2016. "Viina mifam." In Viina i mif edited by Oleksandr Zinchenko, Volodymyr Viatrovych, Maksym Maiorov, 1-11. Kharkiv: Klub Simeinoho Dozvillia.

Zubkovych, Alina. 2019. "Politics of Cinematic Representation of Crimean Tatars in Ukraine: 2003-2018." In "Ukrainian Crimean-Tatar socio-cultural encounters," edited by Kratochvil Alexander. Special issue, Euxeinos - Culture and Governance in the Black Sea Region 9 (28): 47-64.

Zubrzycki, Geneviève. 2017. “The Politics of Jewish Absence in Contemporary Poland.” Journal of Contemporary History 52 (2): 250-277.

\section{Interviews}

Halushko, Kyrylo. 2017. Senior Researcher at the Institute of History of Ukraine of National Academy of Sciences of Ukraine and a Likbez leader. Interviewed by author, February 25. Kyiv.

Pavlov, Vasyl'. 2017. Lecturer of Taras Shevchenko National University of Kyiv and a Likbez member. Interviewed by author, February 24. Kyiv.

Prymachenko, Yana. 2017. Senior Researcher at the Department of the History of Ukraine in 1920s-30s, Institute of the History of Ukraine, National Academy of Sciences of Ukraine, and a Likbez member. Interviewed by author, February 24 . Kyiv.

Yurkova, Oksana. 2018. Leading researcher at the Institute of History of Ukraine, National Academy of Sciences of Ukraine, and a Likbez member. Interviewed by author, September 15. Skype conversation.

\section{History without Censorship Series}

Kniazi i hetmany usiieii Rusi. "Cherez shablu maiem pravo." Zlety i padinnia kozats'koii derzhavy 1648-1783 [Princes and Hetmans of All Rus. "Thanks to the Saber We Are Entitled." Rises and Falls of the Cossack State, 1648-1783].

Lytsari dykoho polia. Pluhom i mushketom. Ukraiins'kyi shliahh do Chornoho moria [Nights of the Wild Fields. Through Plough and Musket. Ukrainian Path to the Black Sea].

Na bii za voliu. Peremoha cherez porazky. Ukraiina u viinah i revolutsiiah 1914-1921 rokiv (To the Battle for Freedom. Victory through Defeats. Ukraine in the Wars and Revolutions 1914-1921].

Narodzhennia kraiiny. Vid kraiu do derzhavy. Nazva, symvolika i kordony Ukraiiny [The Birth of the State: From Region to the State. Name, Symbols and Borders of Ukraine].

Pole Bytvy Ukraiina. Vid "volodariv stepu" do "kiborhiv". Voienna istoria Ukraiiny vid davnyny do siohodennia [Ukraine the Battlefield. From "Lords of the Steppe" to "Cyborgs." War History of Ukraine from Ancient Times to the Present].

Rus' "pislia Rusi”. Mizh koronoiu i bulavoiu. Ukraiinski zemli vid korolivstva Rusi do viis'ka zaporiz'koho (Rus "after Rus." Between the Crown and Mace. Ukrainian Lands from Rus Kingdom to Zaporizhzhia Army].

Tini zhadanyh predkiv. Vid sklavyniv do rusyniv. Pradavnia Ukraiina, Rus' i pohodzhennia ukraiinysiv [Shadows of Recollected Ancestors. From Sklaves to Rusyns. Ancient History of Ukraine, Rus' and Origins of Ukrainians].

U kihtiah dvohlavyh orliv. Tvorennia modernoii natsii. Ukraiina pid skipetramy Romanovyh i Habsburhiv [In Claws of DoubleHeaded Eagles. Formation of the Modern Nation. Ukraine under the Scepters of Romanovs and Habsburgs].

Ukraiina radians'ka. Iluzii ta katastrofy "komunistychnoho raiiu"1917-1938 rokiv [Soviet Ukraine. Illusions and Catastrophes of 1917-1918].

Vid Reihstahu do Ivodzimy. U polumii viiny. Ukraiina ta ukraiintsi u Druhii svitovii viini [From Reichstag to Ivo Jima. In the Flames of War. Ukraine and Ukrainians in the Second World War].

Cite this article: Yurchuk, Y. 2021. Historians as Activists: History Writing in Times of War. The Case of Ukraine in 20142018. Nationalities Papers 49: 691-709, doi:10.1017/nps.2020.38 